\title{
A Sympotic SELF: InSTRUCTION THROUGH INEBRIATION IN ANACREON
}

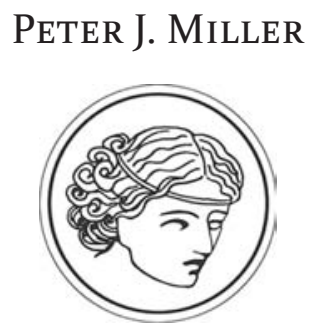

ABSTRACT / RÉSUMÉ

As early as the fifth century, Anacreon was the poet of wine, love, and song; even his death-choking on a pip-is attributed to the grape. The fact that the symposion looms large in the extant fragments is, therefore, hardly surprising. In this article, I examine Anacreon's sympotic verse and its moral quality. While the ethical character of Xenophanes' and Theognis' sympotic fragments has been acknowledged, most scholars consider Anacreon as a poet of love, rather than of moral instruction. Recently, Lear and Hobden have begun to address the moral and instructive character of Anacreon's verse. I build on these analyses by examining the Anacreontic speaker's presentation of moral value through his own person; there are 46 first-person statements in Anacreon, an important fact considering the narrative and psychological potency of "I" statements in early Greek lyric. In contrast to gnomic statements that purport to be generalized prescriptions, Anacreon's performative "I" offers an alternative mode of moralizing delivery. These first persons, however, are not the same person: Anacreon gives a multitude of perspectives on appropriate sympotic behaviour. I read the Anacreontic speaker's diverse and changing persona as a challenging and embodied moral perspective, which destabilizes the idea of a true self, and consequently denies the stereotyping of ancient poetic biography. By enunciating Anacreon's songs, the speaker puts his own body and individuality into play in the "educative" space of the symposion. In Anacreon's verse, the self itself becomes the space on which sympotic instructions-moral imperatives-are inscribed and displayed to others.

Dès le Ve siècle, Anacréon était connu comme le poète du vin, de l'amour et de la chanson ; même sa mort - étouffé par un pépin - est attribuée au raisin. Le fait que le symposion occupe une place importante dans les fragments de son œuvre qui ont survécu n'est donc guère surprenant. Dans cet article, je m'intéresse aux vers sympotiques d'Anacréon et à leur qualité morale. Alors que le caractère éthique des fragments sympotiques de Xénophane et de Théognis a été reconnu, la plupart des chercheurs considèrent encore Anacréon comme un poète de l'amour plutôt qu'un poète moral. Récemment, Lear et Hobden ont commencé à étudier le caractère moral et didactique de la poésie d'Anacréon. Je me base sur leurs analyses pour examiner la présentation de la valeur morale du locuteur anacréontique à travers sa propre personne ; il y a 46 déclarations à la première personne chez Anacréon, une donnée 
importante considérant le potentiel narratif et psychologique des déclarations au « je » dans la poésie lyrique grecque archaïque. Contrairement aux déclarations gnomiques qui prétendent être des préceptes généralisés, le « je » performatif d'Anacréon offre un mode alternatif de discours moralisant. Ces premières personnes ne sont toutefois pas la même personne : Anacréon présente une multitude de perspectives sur le comportement sympotique convenable. J'interprète la persona variée et fluctuante du locuteur anacréontique comme une perspective morale provocatrice et incarnée, qui déstabilise l'idée d'un vrai soi et qui, par conséquent, nie les stéréotypes de la biographie poétique ancienne. En prononçant les chansons d'Anacréon, le locuteur met en jeu son propre corps et sa propre individualité dans l'espace « éducatif » du symposion. Dans la poésie d'Anacréon, le soi devient l'espace dans lequel les préceptes sympotiques - les impératifs moraux - sont inscrits et exposés aux autres.

"I do not like the man who while drinking his wine beside the full mixing-

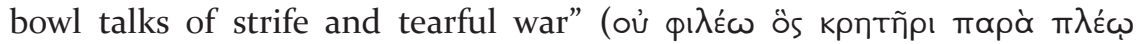

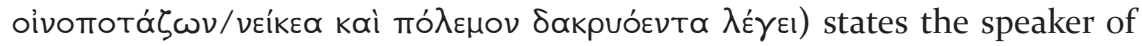
Anacreon's second elegy (2.1-2 W); rather, the speaker prefers to mix love, song, and the "loveliness of the feast" $(2.3-4 \mathrm{~W}) .{ }^{1}$ This passage is a prime example of a sympotic commonplace, talking about the symposium or metasympotic discourse. ${ }^{2}$ Metasympotic discourse deals with more than simply the appropriate table settings, proportion of water to wine, and content of the symposium: considering the symposium's central place in archaic and early classical social and political culture, the drinking party acted as a place for a group to define itself and exclude others. Metasympotic discourse is one way for a poet to instruct his audience and to engage in moral discourse; the explicit ars bibendi of the symposium becomes an implicit ars vivendi for the polis and its citizens, in which in- and out-group members can be identified. ${ }^{3}$ While in Elegy 2, Anacreon outlines a symposium seemingly in accordance with other poets' metasympotic injunctions (e.g., Xenophanes $1 \mathrm{~W}$ ), the poet evinces an interest in the organization of the symposium in more than this poem. This article addresses two metasympotic aspects of Anacreon and the Anacreontic corpus: first, the corpus' particular modulation of "too much" as "just enough" (and its moral quality); second, the way

${ }^{1}$ Unless otherwise indicated, fragments of Anacreon's elegiac poetry are cited from Iambi et Elegi Graeci (= W; West 1992); fragments of lyric are cited from Poetae Melici Graeci (= PMG; Page 1962); testimonia are cited from the edition of Campbell (1988). Elegy 3 W may offer a similar critique, when the speaker dismisses the Cimmerians and Sintians.

${ }^{2}$ Metasympotic discourse is pervasive in poetry composed for performance at the symposium; Xenophanes' verses are perhaps the most explicit (cf. Marcovich 1978), but they are part of a long tradition of symposiasts talking about the symposium (e.g., Thgn. 467-96 W = Euen. 8a W; Critias 6-7 W; Dionys. Eleg. 1-4 W). On the representation of the symposium in sympotic verse, see Hobden 2013: 22-65.

3 On the normative aspect of sympotic writing, see Pellizer 1990: 180; on sympotic poetry and group solidarity, see Rösler 1980. 
in which a persona (a "master symposiast") can be deployed as a moralizing strategy by using body and voice performatively.

\section{"Anacreon," The Sympotic Role}

From as soon as he died, and perhaps even during his lifetime, Anacreon was characterized as the preeminent poet of wine, women, and song (e.g., test. 1, 4, 9; his statue on the Acropolis at Athens represented him "as a man singing when he is drunk" [test. 10 = Paus. 1.25.1]). ${ }^{4}$ By the end of the fifth century at least, Anacreon had entered the Athenian literary imagination. ${ }^{5}$ Snyder interprets Agathon in the Thesmophoriazusae as a literary rendering of the Anacreontic figure familiar from vase painting; Herington suggests that Anacreon's style influenced early-and especially Aeschylean-tragedy; Bing has recently pointed to the Cyclops for more Anacreontic allusions (Eur. Cyc. 495-518). ${ }^{6}$ More pointedly, Athenaeus preserves 10 lines of an elegy by the oligarch Critias that offer much insight into at least one fifth-century sketch of the character of Anacreon, who is a "stimulus for symposia," a "seducer of women," and whose immortality is linked to the passing of cups and the night-long revels of female choruses ( $\mathrm{W}$; cf. Pl. Chrm. 157e6). Anacreon has become, in this poem, a sort of divine or heroic actor for the symposium. ${ }^{7}$ Critias' poem implies that Anacreon can be revived at the symposium (and during female choral rites), and perhaps indicates an Athenian tradition of sympotic role-playing. ${ }^{8}$

When it comes to analyzing Anacreon the historical person and "Anacreon" the sympotic persona, I start from Greg Nagy's well-known

${ }_{4}$ On the statue, see Rosenmeyer 1992: 28. Extant fragments of statues representing Anacreon do not accord with this image, though multiple conventional "Anacreons" were probably available as early as the fifth century (cf. Frontisi-Ducroux and Lissarrague 1983: 16 on Anacreon in vase painting).

${ }^{5}$ On the Athenian reception of Anacreon, see Bing 2014: 26-37. Figures labeled "Anacreon" and other figures in similar costumes appear on Athenian red-figure vases from the beginning of the fifth century; on these and their relation to the historical Anacreon, see Brown 1983; Rosenmeyer 1992: 31-32; Miller 1999.

${ }^{6}$ Snyder 1974; Herington 1985: 110-115; Bing 2014: 40-43.

${ }^{7}$ Critias includes nonsympotic, presumably choral poems, of which we have few remains; on Anacreon's choral songs and their speculative reception in Cyclops, see Bing 2014: 43. Although Critias offers an Anacreon here who is not wholly reduced to erotic and sympotic poetry, we should not understand that the reductive Anacreontic persona did not exist at this point; rather, even when his iambic poetry is referred to, for example, parts of the lyric persona (in this case, an old drunken man) still persist (Bernsdorff 2014: 12).

${ }^{8}$ Rosenmeyer 1992: 17. Fifth-century Athenian literary criticism seems to have stressed biography, and most importantly, the presence of character traits in poetry (see Ar. Thesm. 148-152). Anacreon's physical representation changes across the three inscribed vases (Frontisi-Ducroux and Lissarrague 1983: 16), but the role is nonetheless linked to specific activities: wine, love, and song. 
interpretation of the transmission and reception of Alcaeus. Especially important to my argument is Nagy's identification of the mimetic or generic aspect of the "I" in archaic lyric.9 Since the lyric "I" is mimetic throughout its history and reception, the occasion of the poetry (in Anacreon's case, the symposium) becomes the medium of transmission and reception..$^{10}$ Building on Nagy's discussion, the historical Anacreon and the "Anacreon" of the performance tradition are related, though not by strict biography, since each performance inflects the persona, and the "Anacreon" of performances, even within Anacreon's lifetime, is different from the historical poet." Therefore, I accept "Anacreon," the sympotic role, as part of a diachronic approach to the extant corpus. ${ }^{12}$ The tradition would be potent for those who would quote Anacreon at symposia, since to take on the role of Anacreon was to take on the role of the symposiast par excellence, or to become a "metasympotic spectacle." ${ }^{13}$ I use the terms "Anacreontic speaker" and "Anacreontic corpus" to refer to the tradition of re-enacting Anacreon in symposia and the corpus of poetry associated with this lyric persona..$^{14}$

Issues of reception, reperformance, and tradition are not only external to the corpus. Repetition is found within Anacreon's verse, especially in the

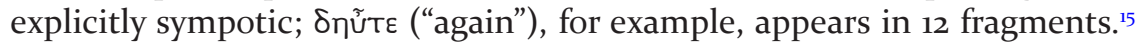
Repetition establishes continuity with the past, when the event previously took place, and implicitly looks forward to the future, when the event is likely to take place again..$^{16}$ The use of $\delta$ บṽ $\varepsilon$ and other significant words erases the originality of the experience, since the event referred to and the reporting of it through verse have already happened. Like Pindar, who skillfully prepares his poetry for repeat performance by effacing any indication of first

9 Nagy 2004: 27-28. For more on Nagy's conceiving of poetic mimesis and poetic identity, see Nagy 1996.

${ }^{10}$ Nagy 2004: 35.

${ }^{11}$ Nagy 2004: 31.

${ }^{12}$ Bing productively compares Anacreon with Elvis, who was impersonated in his own lifetime and, according to a possibly apocryphal story, took part in an "Elvis impersonator" contest. Elvis impersonators generally adopt a reductive vision of Elvis (1950s "bad boy" or 1970 kitsch), in a similar way to Anacreontic impersonators (Bing 2014: 35).

${ }^{13}$ Hobden 2013: 37.

${ }^{14}$ In this article, I do not address the Anacreontea, and thus I build on Bing, who has recently considered Anacreontic performance traditions in the wake of Anacreon the poet, and independent of the Anacreontea (Bing 2014).

${ }^{15}$ Fragments (numbering from $P M G$ ): 349, 356a, 356b, 358, 371, 376, 394b, 40o,

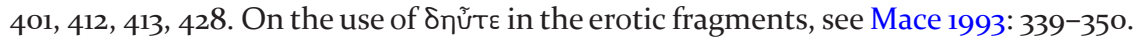

${ }^{16}$ Mace 1993: 338. 
performance, the Anacreontic corpus' heavy use of repetition in vocabulary and theme erases distinctions between first and future performances. ${ }^{17}$

Anacreontic verse therefore generates a poetic persona, a role complete with history and future for prospective symposiasts to imitate and re-enact. ${ }^{18}$ We are encouraged to imagine a continuity of speakers extending forward and backward in time, each one laying claim to an Anacreontic role through the performance of the verse. Since repetition exists even in the original performance, the historical Anacreon can be imagined, counterintuitive as it may seem, as taking on an Anacreontic identity.19 Thus, the corpus' creation of a persona and the early and reductive criticism correlate to a high degree: these two aspects-one literary-critical, one quasi-biographical-structure the way in which the Anacreontic speaker interfaces with tradition and prefigures his own reception within the andrôn.

The fragmentary nature of the corpus is a challenge to any interpretive method, but, in the case of situating Anacreon's verse in the sympotic context, it is not necessarily detrimental. The ancient evidence suggests that symposiasts did not have to quote entire poems-hence the fragmentary quotations retrievable from Athenaeus-and even in the fifth century, the skolion game could be played with portions of lyric poets; Aristophanes cites Alcaeus and Anacreon as examples (fr. 235K-A). In Clouds, Strepsiades asks his son to sing a portion of Simonides or Aeschylus at a symposium (13531379). In the celebrated sympotic lessons in Wasps, singing in accompaniment to the lyre is one of the skills that makes someone sympotikos (1209); men followed each other with snippets from older poets such as Simonides or Stesichorus (schol. ad Vesp. 1222). Therefore, the fragmentary nature of the corpus may be a way to understand the quotation of Anacreon's verse in

${ }^{17}$ On Pindar's skillful manipulation of performance occasion, see Carey 2007: 199.

${ }^{18}$ The fact that so many of Anacreon's verbs are in the present tense (some 70\%: Kantzios 2005: 233) seems to reinforce this idea of a generic and temporally unanchored persona. Kantzios also points out that the first person is extremely common in Anacreon (Kantzios 2005: 231-232).

19 Nagy 2004: 347. The material remains of the symposium also point to the notion that symposiasts could take on conventional or traditional roles. Osborne has detailed the way in which sympotic pottery offered a variety of roles to individuals across activities such as gaming, song, drinking, and sexual advances (Osborne 2007: 33). As such, sympotic ware offers evidence that symposiasts were encouraged to compare themselves and their symposium with those of the vase paintings: different roles were available, and symposiasts could conceive of themselves in union with, or in opposition to, the images painted on these vessels. In like manner, poetry, or quotations from it, especially in the first person, permitted speakers to "conjure in the flesh" the images of the drinking vessels, and to take on or reject a conventional role (Hobden 2013: 36). 
the sympotic setting. ${ }^{20}$ Certainly symposiasts may have known the context of the poem from which a citation was taken, and the context may have played a role in understanding the quotation, but in some cases, at least, the quotation would have been comprehensible without further context. Therefore, this article approaches the corpus of Anacreon as a collection of sympotic quotations, the fragmentary condition of which helps us to understand the historical experience of hearing and reciting poetry in the symposium.

\section{Wine Consumption And Controlling the Sympotic ExPerience}

Wine, drunkenness, and sobriety are themes throughout the corpus. ${ }^{21}$ Since wine, of course, is central to the symposium, the focus on the consequences of indulgence or abstinence makes thematic sense. A focus on wine, however, is not just topical, and the Anacreontic corpus uses the syntax, as it were, of wine consumption in order to structure the quality of the symposium. Considering the communal character of sympotic consumption and the physiological effects of consuming neat or near-neat wine, control over the water-to-wine ratio, for example, effectively controls the sobriety and competency of the fellow drinkers and the type of symposium that occurs. ${ }^{22}$ Since sympotic conversation and singing were passed from person to person, drunkenness (whether individual or communal) affected the tenor of the sympotic experience. ${ }^{23}$ When the Anacreontic speaker recommends or commands a particular ratio or when he announces his inebriation, he is doing more than getting himself drunk; he is attempting to control the

${ }^{20}$ For the ancient evidence for the skolion game and its connection with lyric composition and performance see Collins (2004: 84-98; on the passage from Wasps, see 99-110).

${ }^{21}$ Anacreon's corpus was a prime place to find words about drinking: see $P M G$ 454, 455 .

${ }^{22}$ Control of the symposium via drinking is explicitly indicated in Plato's Symposium, when Pausanias asks "what way will we drink best?" (176a5-6). While the others are hung over from a previous night of drinking, Eryximachus observes that Socrates is "fit either way" (176c4) - a truly master drinker. Indeed, in the end, the decision about how much to drink is left in the hand of each symposiast (176e4-5). In the case of Anacreon's sympotic verse, as we shall see, such control is generally jealously guarded by the Anacreontic speaker.

${ }^{23}$ Various ratios for mixing wine are attested: in Od. 9.208, the Maronean wine that is given to the Cyclops is mixed 20:1 (water to wine); Pliny states that this wine, in his day, is still strong, and is now mixed 8:1 ( $H N$ 14.6); Hesiod recommends a 3:1 ratio (Op. 596). Athenaeus' discussion is the best collection of evidence for water-towine ratios and ancient opinions (Athen. 430a-431e). Kantzios argues that Anacreon's ratios are modest (2005: 229), and there is some confusion in the scholarship about whether PMG 409 calls for five parts water and three parts wine (Kantzios 2005: 229) or the other way around (Campbell 1988). In any case, the relative strength would be most affected by the type of wine, and this is beyond our knowledge. 
symposium. ${ }^{24}$ The enforcement of particular ratios of water to wine could be part of sympotic play and masculine display, since the symposiast should be poised on the edge of drunkenness and embarrassment to prove masculine ability in imbibing, but also in self-control. ${ }^{25}$ In this environment, at once convivial and competitive, the Anacreontic persona provided a means of pushing the limits of sympotic activity and concurrently proving the acumen of the individual symposiast.

The traditional aspect of the Anacreontic persona means that to take control of sympotic drinking is to take control as "Anacreon"; the corpus intensifies the actual symposium by reinforcing it with the imaginative re-enactment of the lyric "I." ${ }^{26}$ The "presentness" of Anacreontic verse, the pervasive persona and its reception, and the overwhelming number of first-person statements emphasize the individual: the Anacreontic corpus configures its sympotic instruction around one character, the persona, who controls and leads through his own speech and action. The group, in contrast, exists merely as implicit foil to the "master symposiast."

The dynamic of control and inebriation and the emphasis on the "I" are most obviously demonstrated in a series of three fragments that concern the ratio of water to wine: $P M G$ 356a, 356b, and 409:27

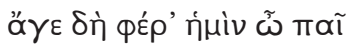

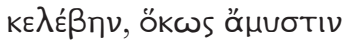

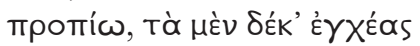

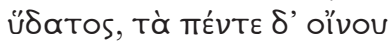

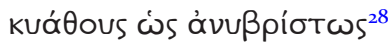

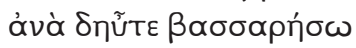

${ }^{24}$ His practice may also challenge received sympotic decorum; see Henderson 1999: 3. The rhetoric of Xenophanes $1 \mathrm{~W}$ suggests that moderate consumption was not always - or perhaps even often-the case. Alcibiades' appearance near the end of Plato's Symposium- “exceedingly drunk" (212d4) - changes the tenor of the conversation and attempts to alter the sedate symposium that has, until that point, proceeded (e.g., at 213e7-10).

25 On display and masculinity here, see Osborne 2007: 34 .

${ }^{26}$ Hobden 2013: 37-38; on the lyric "I" more generally, see Slings 1990.

${ }^{27}$ In another fragment ( $P M G_{3} 83$ ), we have a description of a serving-girl bringing in a "three-ladle bowl," though this simply means a cup that could hold three ladles of wine. The fragment does not specify the ratio of water to wine. At $P M G 396$, the speaker commands that water and wine be brought forth for his combat with love, but the specific ratio is left unmentioned.

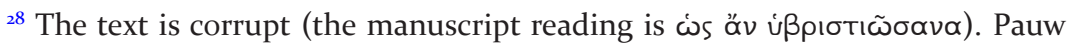

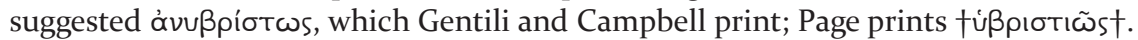
I follow Pauw's conjecture, which has been defended most recently by Tsomis (2001: 163-165). 'óvußpíotws is rare, though at least attested, and the sense of the fragment surely requires a drinking style that does not cause offense. 
Come, boy, bring me a bowl, so that I may drink without stopping for breath; pour in ten ladles of water and five of wine, that I may once again play the Bacchant with decorum $(P M G 356 a){ }^{29}$

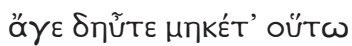

$\pi \alpha T \alpha \dot{\gamma} \varphi \omega \tau \kappa \kappa \dot{\alpha} \lambda \alpha \lambda \eta T \tilde{\omega}$

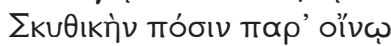

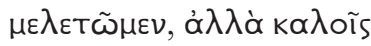

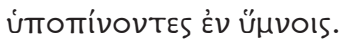

Come again, let us no longer practice Scythian drinking with clatter and shouting over wine, but drink moderately amid beautiful songs of praise (PMG $356 \mathrm{~b}) .^{30}$

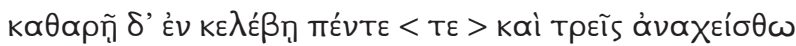

and let the mixture be poured in a clean bowl, five (of wine) and three (of water) (PMG 409).31

In 356a, the Anacreontic speaker demands that a serving boy mix a specific ratio of water to wine (10 to 5); he also asks for the same boy to bring him

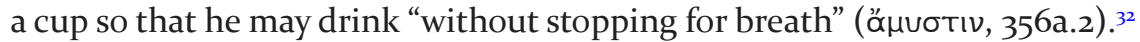
The consequence of these two activities is explained in lines five and six, where the speaker claims that (as a result of this drinking) he will once again "without being hubristic break forth in Bacchic frenzy" (356a.7). ơvußpíotws is hardly a common word, but the sense here must be that to "break forth in Bacchic frenzy" would normally elicit rebuke, but if the person is drinking, such behaviour is understandable. ${ }^{33}$ While the speaker addresses only himself in this short quotation, the communal sympotic drinking practice means that all the participants are implicated in this strong wine drinking, and, furthermore, that they all gain access to the same license that strong drink permits. The Anacreontic speaker, using this fragment, controls the quality of the wine, and at the same time the quality of the symposium. He does so, not with gnomic statements or opinions, but by using his own voice and body. óvußpíotws must be a value statement on the nature of this particular instance of drunkenness, and the speaker's first-person declaration,

29 Translation: Campbell 1988.

30 Translation: Campbell 1988.

${ }^{11}$ Translation: Campbell 1988.

32 The excerpt asks us to understand a strong mixture, or at least a mixture that excuses-or licenses-drunkenness (see Hobden 2013: 48, n. 52).

33 We might compare, from the Anacreontea, the idea of "sane madness" (Anacreont. 2.6). Tsomis observes that "to be a Bacchant" here may refer to drinking mixed wine (Tsomis 2001: 164). 
no less than a set of apparently objective commands, acts performatively, but also mandates the reception of his activities among the other participants. ${ }^{34}$

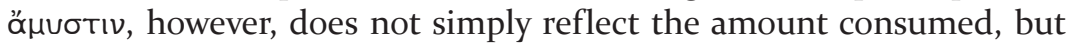
also the technique of drinking. Robin Osborne instructively considers how difficult drinking quickly and "without stopping for breath" would be with an assortment of ancient drinking cups. He remarks that to drink quickly from some extant skyphoi and especially kylikes would be quite difficult. ${ }^{35}$ Thus, drinking åuuvтiv should not be seen only as indulgence, but as a display of sympotic skill. Virtuoso drinking, as it were, is part of the sympotic acumen of the Anacreontic speaker. There is, after all, a marked difference between clumsily gulping down a cup of wine while it splashes onto your face and clothes, and skillfully finishing an entire cup without spilling a drop: the result-drunkenness-may be the same, but the display of drinking in the latter is not without skill. ${ }^{6}$ In fact, as Georgios Tsomis argues, the Anacreontic speaker here may be using his superlative wine-drinking ability so that a new mixture may be poured as quickly as possible; drinking quickly thus provides further opportunity to control the symposium. ${ }^{37}$

Sympotic skill is a crucial component of the Anacreontic persona and covers more than just drinking. In $P M G 374$ the speaker strikes the $\mu$ ó $\gamma \alpha \delta ı$ : "holding the magadis, I strike its twenty strings, while you Leucaspis,

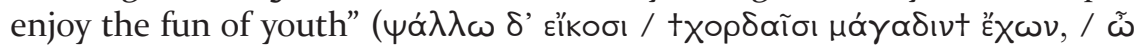

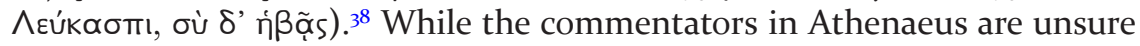
what the $\mu \alpha \gamma^{\prime} \alpha \delta 15$ is exactly (see Athen. 14.634c), as far as the Anacreontic corpus represents it, its 20 strings would make it extremely difficult to play properly. Once again, the sympotic skill (and the typically aged persona) of the Anacreontic speaker is on display with his own body, since he declares his actions and implies a contrast in age with the proposed audience, a Leucaspis, who "enjoy[s] the fun of youth" (374.2). Lyre-playing at the symposium should, in fact, not be separated from drinking, since the two are

${ }^{34} P M G 365$ is an etymological gloss explaining Anacreon's spelling of Dionysus, and cites the phrase "loud-roaring Dionysus." This epithet fits the type of Dionysus conjured up by strong drink. In PMG 442 someone "revels like Dionysus" and the scholiast claims that "the poet compares himself to Dionysus in this fragment" (Schol. T ad Hom. Il. 19.21).

35 Osborne 2007: 36.

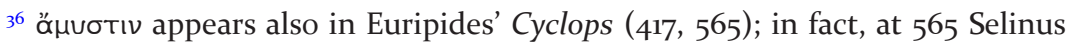
applauds Polyphemus' excellent drinking, though the consequences of drinking

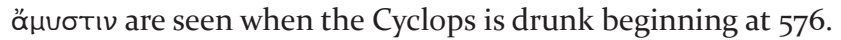

37 Tsomis 2001: 164 .

${ }^{8}$ Translation: Campbell 1988. The text at 374.2 is corrupt, though the reading of $\mu$ ó $\gamma \alpha \delta ı$, in some form or another, is kept in most conjectures. Moreover, the surrounding commentary in Athenaeus discusses the $\mu$ ó $\gamma \propto \delta \delta$ s explicitly, and thus we should expect to find it in the fragment of Anacreon. 
the essential components of sympotic play and characteristic of the master symposiast. ${ }^{39}$

356a is accompanied in Athenaeus by 356b. It is uncertain from their context whether the fragments come from the same poem, since Athenaeus intercedes with пров $\lambda \theta \omega$ ' belong together-or at least could be deployed together-because they both interface with the Anacreontic control (and creation) of a particular type of symposium. ${ }^{4^{\circ}}$ Athenaeus' speaker cites $356 \mathrm{~b}$ because it supplements his discussion of the appropriate ratio of water to wine: in the fragment the Anacreontic speaker uses the first person plural ( $\mu \varepsilon \lambda \varepsilon \tau \tilde{\tau} \mu \varepsilon v: 356 \mathrm{~b} .4$ ) to call for moderate (intomívoves: 356b.5) drinking and to ask that the company cease from "Scythian drinking" and the accompanying noise-making (356b.2-3). "Scythian" drinking (i.e., to drink wine neat) is attested in archaic and classical literature and figured art; the Kleophrades Painter even incorporates a "Scythian," wearing the sakkos, into a scene with a figure labelled "Anacreon." 41

$356 \mathrm{~b}$ is thus another attempt to control the symposium. The prior type of drinking, realized in the actual symposium in which this fragment would follow 356a, was loud and disorderly; the command to do so "no more" implies that Scythian drinking was exactly what the symposiasts were doing. In sequence both fragments reinforce the authority of the persona: in 356a, he leads the group toward Bacchic revelry; in $356 \mathrm{~b}$, he calls on them to stop their Scythian drinking. In fact, the fragments construct a narrative in which

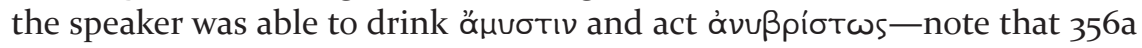
uses the first person singular-but his companions were unable to maintain this imbibing pace and preserve decorum amidst the consumption of so much wine; hence the switch to the first person plural in 356b. The verse sequence allows the Anacreontic speaker to lead the symposiasts to the edge of drunkenness, but then to turn back and demand a new mixture of water and wine (hence the repetition of 'o $\gamma \varepsilon$ ) only when it becomes clear that he, and he alone, can manage the required imbibing. In an actual symposium, $356 \mathrm{a}$ and $356 \mathrm{~b}$ could also be delivered in response to one another (akin to the skolion game) and thus different visions of the Anacreontic persona could

39 Lissarrague 1990: 32.

$4^{\circ}$ They could be performed in response to one another (per the skolion game; see Hobden 2013: 51). Tsomis argues against the two fragments belonging to the same poem, because "Scythian drinking" (356b.3) does not appear in the first excerpt, and thus the two, assuming no lost intervening lines, do not make sense (Tsomis 2001: 165). Since I am interested in their potential deployment in many symposia, the question of internal sense in a conjectural poem is of less importance. Pretagostini, while arguing for a single poem as the source for both fragments, points to their construction of different modalities of symposia, a position that I think is borne out in the fragments (Pretagostini 1982: 54).

${ }^{41} A R V^{2} 184.32$ (= Beazley Archive no. 201684). 
be used by symposiasts to playfully, but seriously, contest the group's sympotic practice. The power of these verses to respond using the medium of the persona is heightened, since they both deploy $\delta$ vĩt $(356 a .6 ; 356 \mathrm{~b} .1$ ), which implicates the tradition of re-enacting "Anacreon" in the actions of the individual speakers.

409 is another attempt to control consumption; the ratio is slightly weaker than in 356a-five to three-but all the same the speaker tries to gain control of sympotic conduct through wine consumption. Across 356a, 356b, and 409, sympotic control is manifested through the control of wine drinking. Regulation of this sort is especially designed to avoid confrontation by controlling sympotic conduct at one step removed, via wine, rather than via direct commands. In 356a in particular, the speaker deploys an even more efficacious tactic, because performative speech and the Anacreontic persona allow the symposiast to command, perform, and evaluate his actions simultaneously. The space for rejection is removed, and the speaker effectively controls the symposium while at the same time militating against the possibility of conflict.

Conflict and peaceful coexistence, within the confines of the group, were part of the rationale for the institutionalized symposium. The battle between the Lapiths and Centaurs was seen as a paradigm of the opposition of symposium and conflict; eunomia, a political (and lyric) axiom, was also regarded as a sympotic ideal (cf. Bacchyl. 13.186)..$^{42}$ Harmony was crucial, and the symposium operated to demarcate identities within the group, but also to distinguish the group from the others outside the drinking party.43 Thus, by displacing the question of sympotic conduct onto the question of the mixture of wine, or by establishing a new sympotic direction with his own body, the Anacreontic speaker effects his purpose and circumvents any conflict; or, at least, he removes from himself the culpability for beginning a conflict.

One consequence of drinking lots of wine-mixed or unmixed, strong or weak, and certainly "without stopping for breath"-is drunkenness. Several times throughout the corpus, the speaker finishes his drink and must be at least moderately inebriated. In PMG 433, we see further evidence of the Anacreontic persona's skilled drinking mixed with drunkenness: "and I held a full

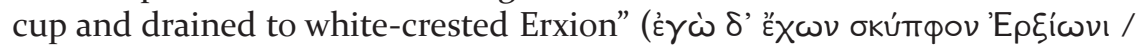

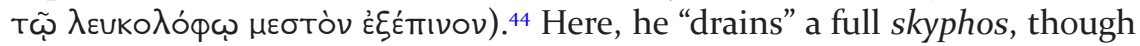

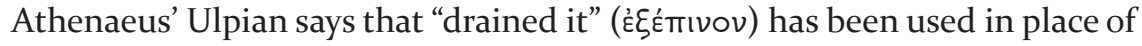

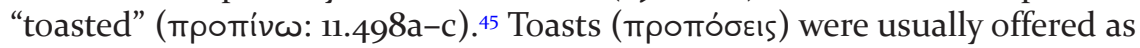

${ }^{42}$ Lissarrague 1990: 28; on Eunomia specifically, see Slater 1981: 207 and Bowie 1997.

43 Kantzios 2005: 227.

44 Translation: Campbell 1988.

${ }^{45}$ Anacreon plays with the meaning of тро́тоовıs at other times: in PMG 407, he uses the metaphor of the toast to ask for the thighs of a young man, rather than the half-empty cup. 
the wine-pourer passed from left to right, and the про́тоог could involve praise of the individual to whom the partially full cup was given (cf. Dionys. Eleg. $1 \mathrm{~W}) .{ }^{46}$ The change in vocabulary in this fragment subtly highlights the acumen and the priorities of the Anacreontic speaker at the same time as it once again focuses on the individual at the expense of the group; after all, he passes on an empty cup to the next symposiast.

The first person can also re-enact the Anacreontic persona through narration:

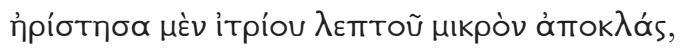

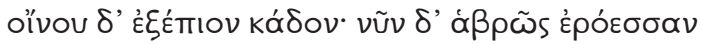

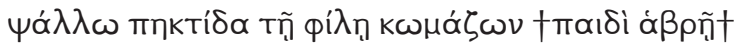

I dined by breaking off a small piece of thin honeycake, but I drained a jar of wine. Now I tenderly strike my lovely lyre in a serenade to my dear girl $(P M G$ 373).47

After a brief story (of a morning started with drink!), at the end of the second line, $v \tilde{v} v$ turns to the place and time at hand, and the actions that the speaker performs in that very moment: "now I tenderly strike my lovely lyre in a serenade to my dear girl" (2-3). As in 356a and 356b, the Anacreontic speaker highlights song and imbibing as the essential elements of the symposium, coincidentally the very areas in which the persona excels.

While explicit drunkenness in the corpus is slightly rarer, it can also be used to emphasize the ability of the Anacreontic persona. In $P M G$ 412, the first-person attests to his own drunkenness ( $\mu \varepsilon \theta$ úov $\tau^{\prime}$ ) and begs to be allowed to go home (oî́k $\alpha \delta^{\prime}$ ámז $\lambda \theta \varepsilon \tilde{\imath} v$ ), an unusual admission in the sympotic context..$^{8}$ Other sympotic poets remark on the limits that should be imposed on drinking (e.g., Thgn. 211-212, 497-98, 509-510, 837-40 W, Xenophanes 1 W, and Euenus $2 \mathrm{~W}$ ): Xenophanes, for example, expressly advises that one should drink as much as one can handle and still be able to walk home alone (1.17-18 W). As the speaker of lines attributed to Theognis and Euenus says, "it's not possible to have a good time every night" (Thgn. 474-Euenus $8 \mathrm{~W}$ ), and one can therefore infer that wine is best consumed moderately. Needless to say, the Anacreontic speaker offers a different opinion on drunkenness and implicitly rebukes this moderate stance, since for him drunkenness is the signal to go home, the state to which one aspires rather than that which one avoids (also part of the elegiac tradition: see Thgn. 211-212, $492 \mathrm{~W}$ );

${ }^{46}$ Bowie 1993: 360.

47 Translation: Campbell 1988.

${ }^{48}$ Williamson 1998: 44. Perhaps also in PMG 421 ("and my wits have been numbed"), though in this case we have no key words to signify context-certainly the phrase could have uttered by a symposiast in the Anacreontic mode in order to describe drunkenness. 


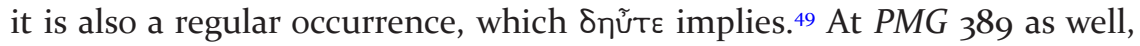
the Anacreontic speaker may engage with, and implicitly dismiss, the moderate stance when he asks a "girl friendly to strangers" to give him a drink, since he is thirsty..$^{\circ}$ The Theognidean corpus expresses the opposite perspective when the poet claims that drunkenness and thirst are the "twin demons ( $\kappa \tilde{p} \rho \varsigma$ ) of drink" (837). Thirst in the Anacreontic corpus signals drink and for the reciter of Anacreontic wisdom, "a good time" certainly could happen every night (cf. Thgn. $474 \mathrm{~W}$ ), though such revelry may only be possible for the Anacreontic speaker-the hero of the symposium-who can tame Theognis' kñpes $(837 \mathrm{~W})$.

The Anacreontic speaker extends the license that drunkenness provides through metaphor, especially in erotic - though still sympotic-contexts. ${ }^{51}$ While love is not strictly metasympotic discourse, the theme is at home in the symposium, and, as we see in PMG 346 (fr. 4) and 396, the Anacreontic speaker connects the symposium to eroticism through wine. Thus, eroticism, no less than drink and song, is another element of the speaker's sympotic prowess and contributes to the construction of the symposium through his actions. Since the Anacreontic corpus fuses eroticism with drunkenness for the first time, the speaker's drunkenness interfaces, in fact, with his amatory self-presentation.

For Servius, the phrase "drinking love" was a clear allusion to the drinking party, so much so that he glossed Dido's bibebat amorem (Verg. Aen. 1.749) with reference to Anacreon ( $P M G$ 450). In $P M G$ 376, the metaphor is deployed in a first-person fragment cited by Hephaestion for its metrical qualities: "See, once again I climb up and dive from the Leucadian cliff

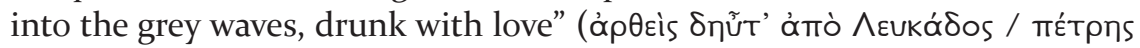

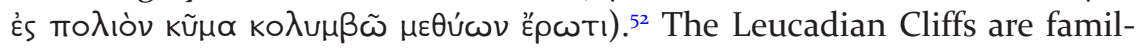
iar from a Sapphic testimonium, where a jump was supposed to cure lovewhether because of magical or fatal effects is unclear (Sapph. test. 23). In any

49 The abundance of material concerned with sympotic decorum proves that sympotic criteria were open to challenge (Hobden 2013: 56). The speaker in Theognis is more explicitly antagonistic than the Anacreontic speaker, since he positions himself in conflict —or at least debate-with another symposiast. If Thgn. 467-497 $\mathrm{W}$ is a conflation of three separate poems in response to one another (see Faraone 2008: 91-92), then the antagonistic aspect, which would certainly be at home in the sympotic environment, is heightened.

$5^{\circ}$ We might compare Eryximachus' complaint to Alcibiades in the Symposium,

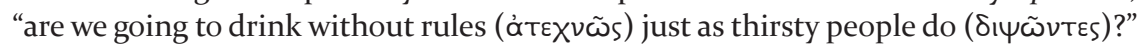
(Pl. Sym. 214b2), which seems to indicate that thirst and excessive drink might go together.

${ }^{51}$ On the erotic poems of Anacreon and their connection to the construction of an alternative self for archaic Greek males, see Lear's highly persuasive reading (2008).

${ }^{52}$ Translation: Campbell 1988. 
case, we can categorize such a leap as a wild and shameful thing (cf. Thgn. 479-481), and Anacreon qualifies and justifies such an action with the last words of the fragment, "drunk with love." As in the case of 412 and 356a, drunkenness, if only metaphorical in this case, combined with first-person speech, authorizes the action and militates against possible rebuke; the

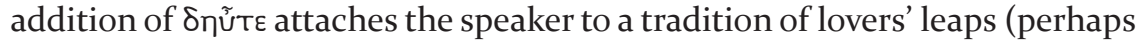
even alluding to the tradition of Sappho) and adds an element of humour, since the purported suicidal plunge has been, paradoxically, completed time and time again.

Finally, in Elegy $4 \mathrm{~W}$, perhaps the most explicit first-person statement in the Anacreontic corpus appears: "and I have become a wine-drinker"

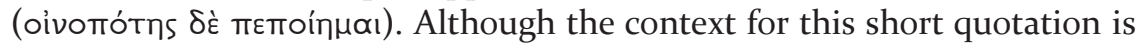
lacking entirely, it encompasses the type of person that is created in the broken and partial Anacreontic oeuvre. Three words suffice to manifest "Anacreon" and to ignore other visions of the symposium; this may be a statement of fact, a challenge, or even a guilty admission. This sort of phrase evokes the entire corpus, since Toó $\omega$ simultaneously suggests the crafting of an identity and the crafting of song: the speaker conceives his own identity (and argues for the essential connection of symposia and wine) and observes his part in the tradition of "Anacreon," which has, by his own enunciation, "made him

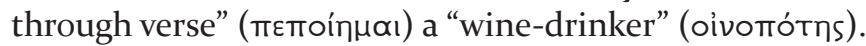

Thus, the Anacreontic corpus-those specific poems attributed to Anacreon in his lifetime and immediately thereafter-crafts a role for prospective symposiasts to deploy in the heightened context of the symposium. The persona finds license in drink (whether for hubris or love affairs), but also negotiates control of the sympotic revelry through the control of drink, and through the Anacreontic speaker's sympotic skill. If the persona operates explicitly in these fragments to monitor, judge, and control, when we move to the reception of the Anacreontic speaker, the persona becomes a medium through which the very practice of ethics can operate.

\section{THE ETHICS OF INEBRIATION}

Nagy and Bremmer have identified the symposium as a locus for moral discrimination and education, and Andrew Lear has previously compared the Socrates of the Symposium and Anacreon. ${ }^{33}$ For Lear, Anacreon is a "forerunner" for Socrates, especially when it comes to their respective abilities to drink without causing offence. Anacreon never "leaves" the realm of the erotic, but clearly, at least in the Symposium, the world of eroticism, drunken license, and symposia can be productive for ethical thinking. ${ }^{54}$

Building on Lear's inchoate connection of Plato's Socrates and Anacreon, it is striking that in the Laws, Plato finds a way to integrate irrationality, and

53 Especially in the archaic symposium: see Bremmer 1990; Nagy 2004: 46; Lear 2008: 72 .

54 Lear 2008: 72. 
particularly wine consumption, into his city. ${ }^{55}$ Wine's benefit is that it temporarily strengthens antirational desires and emotions, and therefore proper consumption of wine-and getting drunk - gives citizens the ability to practice the constant conflict that is at the heart of sophrosyne. Plato explicitly connects this to lifelong education, since he claims that the type of madness brought about by wine makes the drinker like a child, "more easy to mould" (Leg. 671b-c). Wine absolves us of shame and makes older citizens more likely to dance and sing (cf. Od. 14.463-466), that is, to return to the basic childhood education that Plato believes encodes good and bad in good and bad music (Resp. 401e1-402a4). The interest in returning to a state of childish innocence and a naïve knowledge of virtue explains Plato's insistence that only older citizens - those over 40-partake of enough wine to get drunk (Leg. 653b3-a3). Thus, we have in this late dialogue the idea that drunkenness was particularly useful for older men, who could sing and dance, and in doing so, strengthen or obtain a knowledge of virtue. ${ }^{6}$ While the Anacreontic speaker may not explicitly prefigure the late Plato, the standard Anacreontic character is an old man (e.g., PMG 358 and 395 and Antipater Anth. Pal. 7.27.18), and the speaker evinces the benefits of drunkenness and its incorporation into his identity; he has, after all, been made a wine-drinker. Can we see, in the Anacreontic corpus, a nascent moral system-or only its inspiration - that offered an alternative medium to the normal, antiwine, philosophical symposium of Plato (cf. Resp. 559b8-c1 on the dangers of gluttony; Resp. 398e6-7 on prohibiting the guardians from drinking; Symp. 176a-d on the restrictions concerning drinking on that occasion), and to which the philosopher turned, finally fully recognizing the moral qualities of the poet he once called "Anacreon the wise" (Phdr. 235c3; cf. Leg. 672a5-7)?

\section{ACKNOWLEDGMENTS}

My thanks to Bill Allan and Laura Swift for organizing the colloquium for which I wrote this article. My further thanks are owed to my fellow symposiasts for their insightful comments and questions and for the intellectual stimulus of their own articles over the two days; I should add my gratitude to Carla Manfredi, who read this article in various drafts and provided invaluable feedback, and to the two anonymous reviewers. As a result of inane bureaucracy, I was prevented from attending the colloquium in person, but the technological wizardry of Memorial University and the patience and assistance of Brad Levett permitted me to attend via videoconference and therefore to take in all but the most literally sympotic aspects.

Classics,

UNIVERSITY OF WINNIPEG

peter.miller@ttu.edu

55 Belfiore 1986: 421.

${ }_{56}^{6}$ The "gymnastics of pleasure," as Pellizer puts it (Pellizer 1990: 183). 


\section{PETER J. MiLLER}

\section{REFERENCES}

Belfiore, E. 1986. "Wine and Catharsis of the Emotions in Plato's Laws," CQ 36: 421437. https://doi.org/10.1017/Sooog838800012167.

Bernsdorff, H. 2014. “Anacreon's Palinode," in M. Baumbach and N. Dümmler (eds.), Imitate Anacreon! Mimesis, Poiesis, and the Poetic Inspiration in the Carmina Anacreontea. Berlin: De Gruyter. 11-24. https://doi.org/10.1515/9783110334142.11.

Bing, P. 2014. “Anacreontea avant la lettre: Euripides' Cyclops 495-518," in M. Baumbach and N. Dümmler (eds.), Imitate Anacreon! Mimesis, Poiesis, and the Poetic Inspiration in the Carmina Anacreontea. Berlin: De Gruyter. 25-46. https://doi. org/10.1515/9783110334142.25.

Bowie, A.M. 1997. "Thinking with Drinking: Wine and the Symposium in Aristophanes," JHS 117: 1-21. https://doi.org/10.2307/632547.

Bowie, E.L. 1993. “Greek Table-Talk before Plato," Rhetorica 11: 355-371. https://doi. org/10.1525/rh.1993.11.4.355.

Bremmer, J. 1990. "Adolescents, Symposion, and Pederasty," in O. Murray (ed.), Sympotica: A Symposium on the Symposion. Oxford: The Clarendon Press. $135-148$.

Brown, C.G. 1983. "From Rags to Riches: Anacreon's Artemon," Phoenix 37: 1-15. https://doi.org/10.2307/1087310.

Campbell, D. 1988. Greek Lyric II. Cambridge, MA: Harvard University Press.

Carey, C. 2007. "Pindar, Place, and Performance," in S. Hornblower and C. Morgan (eds.), Pindar's Poetry, Patrons, and Festivals: From Archaic Greece to the Roman Empire. Oxford: Oxford University Press. 199-210.

Collins, D. 2004. Master of the Game: Competition and Performance in Greek Poetry. Washington, DC: Center for Hellenic Studies.

Faraone, C. 2008. The Stanzaic Architecture of Early Greek Elegy. Oxford: Oxford University Press.

Frontisi-Ducroux, M., and F. Lissarrague. 1983. "De l'ambiguïté à l'ambivalence-Un parcours Dionysiaque," Instituto Universitario Orientale: Annali del Seminario di Studi del Mondo Classico: Archeologia e Storia Antica 5: 11-32.

Henderson, W.J. 1999. "Men Behaving Badly: Conduct and Identity at Greek Symposia," Akroterion 44: 3-13.

Herington, J. 1985. Poetry into Drama: Early Tragedy and the Greek Poetic Tradition. Berkeley: University of California Press.

Hobden, F. 2013. The Symposium in Ancient Greek Thought. Cambridge: Cambridge University Press. https://doi.org/10.1017/CBO9781139208444.

Kantzios, I. 2005. "Tyranny and the Symposium of Anacreon," CJ 100.3: 227-245.

Lear, A. 2008. "Anacreon's 'Self': An Alternative Role Model for the Archaic Elite Male?" AJPh 129: 47-76.

Lissarrague, F. 1990. The Aesthetics of the Greek Banquet. Trans. A. Szegdy-Maszak. Princeton, NJ: Princeton University Press. https://doi.org/10.1515/9781400861156.

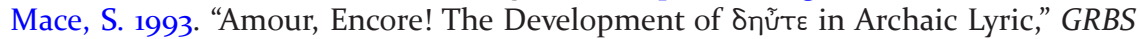
34: 335-364.

Marcovich, M. 1978. "Xenophanes on Drinking-Parties and Olympic Games," ICS 3: $1-26$.

Miller, M. 1999. "Reexamining Transvestism in Archaic and Classical Athens: the Zewdaski Stamnos," AJA 103: 223-253. https://doi.org/10.2307/506746.

Nagy, G. 1996. Poetry as Performance. Cambridge: Cambridge University Press.

- 2004. "Transmission of Archaic Greek Sympotic Songs: From Lesbos to Alexandra," Critical Inquiry 31: 26-48. https://doi.org/10.1086/427301. 
Osborne, R. 2007. "Projecting Identities in the Greek Symposion," in J. Sofaer (ed.), Material Identities. Malden, MA: Blackwell. 31-52. https://doi.org/10.1002/ 9780470694091.ch2.

Page, D. 1962. Poetae Melici Graeci. Oxford: Oxford University Press.

Pellizer, E. 1990. "Outlines of a Morphology of Sympotic Entertainment," in O. Murray (ed.), Sympotica: A Symposium on the Symposion. Oxford: The Clarendon Press. 177-184.

Pretagostini, R. 1982. "Anacr. 33 Gent. = 356 P: Due modalità simposiali a confronto," QUCC 10: 47-55.

Rosenmeyer, P. 1992. The Poetics of Imitation: Anacreon and the Anacreontic Tradition. Cambridge: Cambridge University Press.

Rösler. 1980. Dichter und Gruppe. Munich: Wilhelm Fink Verlag.

Slater, W.J. 1981. "Peace, the Symposium, and the Poet," ICS 6(2): 205-214.

Slings, S. 1990. "The I in Personal Archaic Lyric: An Introduction," in S. Slings (ed.), The Poet's I in Archaic Greek Lyric: Proceedings of a Symposium held at the Vrije Universiteit Amsterdam. Amsterdam: Vrije Universiteit Press. 1-30.

Snyder, J. 1974. "Aristophanes' Agathon as Anacreon," Hermes 102: 244-246.

Tsomis, G. 2001. Zusammenschau der frühgriechischen monodischen Melik: Alkaios, Sappho, Anakreon. Berlin: Franz Steiner Verlag.

West, M. 1992. Iambi et Elegi Graeci. Oxford: Oxford University Press.

Williamson, M. 1998. "Eros the Blacksmith: Performing Masculinity in Anakreon's Love Lyrics," in L. Foxhall and J. Salmon (eds.), Thinking Men: Masculinity and Its Self-Representation in the Classical Tradition. New York: Routledge. 71-82. 